\title{
Prosthetic status and treatment needs for lost masticatory function in haemodialysis patients
}

Magdalena Wilczyńska-Borawskaํ, Jolanta Małyszko², Dorota Cylwik-Rokickaª , Michał Myśliwiec

1Department of Conservative Dentistry, Medical University of Bialystok, Poland 2Nephrology and Transplantology Clinic with the Dialysis Centre, Medical University of Bialystok, Poland

${ }^{3}$ Department of Prosthodontics, Medical University of Bialystok, Poland

Submitted: 16 April 2011

Accepted: 31 July 2011

Arch Med Sci 2012; 8, 1: 81-87

DOI: $10.5114 /$ aoms.2012.27286

Copyright (c) 2011 Termedia \& Banach

\section{Abstract}

Introduction: Premature loss of permanent teeth leads to stomatognathic system disability. It is a very serious but underrated problem for patients with chronic renal failure. The aim of study was analyse the degree of loss of masticatory function and number of teeth present for haemodialysis patients, and to define patients' needs for prosthetic treatment, which could restore correct occlusal condition.

Material and methods: Sixty-nine haemodialysis patients treated at the Nephrology and Transplantology Clinic with the Dialysis Centre at the Medical University of Bialystok, Poland. We checked: 1) the total number of teeth and number of teeth separately for upper and lower jaws, 2) the existing prosthetic restorations and 3) the preserved masticatory function.

Results: More male than female patients were in possession of full dentition.All patients with at least 28 natural teeth with retained occlusal contacts whilst chewing were males (4; $10 \%$ males; $5.7 \%$ of the whole group). There were 15 edentulous patients: 7 males (10\%) and 8 females (11.5\%). Hundered percent of female patients presented with various degrees of tooth loss and needed prosthetic treatment. Nearly $70 \%$ of tested haemodialysis patients did not have a reconstructed masticatory function.

Conclusions: The population of haemodialysis patients from the North East part of Poland are patients with severe stomatognathic system dysfunctions. It is of importance for dentists, as well as nephrologists, to understand the essence of the problem, as the general health of a patient cannot be improved without ensuring functional comfort of such as important system as the masticatory one.

Key words: chronic renal failure, haemodialysis, teeth loss, prosthetic restoration, masticatory function.

\section{Introduction}

One of the most important aims of dentistry, irrespective of the specialization, is the preservation of masticatory function. Masticatory function is defined as the presence of occlusal contacts between at least 20 opposing natural teeth and/or prosthetic restorations [1, 2]. Premature loss of permanent teeth leads to stomatognathic system disability, loss of masticatory functions, and alterations in speech and face aesthetics [3]. It may manifest as TMJ problems, a buzzing noise in ears, increased mobility and overloading causing damage of the remaining teeth, gastric
Corresponding author: Magdalena Wilczyńska-Borawska PhD Department of Conservative Dentistry Medical University 24A M. Skłodowskiej-Curie 15-276 Bialystok, Poland Phone/fax: +48 857421774 E-mail: magdalena.borawska@e.pl 
problems as a result of difficulties in food mastication and dietary changes caused by eliminating raw vegetables and fruits $[3,4]$.

Loss of masticatory function, especially at a young age, may result in severe malocclusion which, if not treated, may lead to irreversible dysfunction of the whole masticatory system (teeth, alveolar bone, marginal and apical periodontium and the temporo-mandibular joints) [3, 4]. In addition, some gastric problems may be evident [4]. Edentulous patients withdraw earlier from professional and social life and their quality of life rapidly decreases [5].

Premature loss of permanent teeth is a very serious but underrated problem for patients with chronic renal insufficiency $[6,7]$. This is a result of general disease status, pharmacotherapy usage and coexisting systemic diseases (e.g. diabetes, high blood pressure, osteodystrophy) [8-12]. As a result of high concentration of urea in saliva, constant changes in composition and $\mathrm{pH}$ of saliva (especially for haemodialysis patients), xerostomia, malnutrition and/or specificity of diet, stress, calciumphosphate disequilibrium, reduced humoral and cellular immunity, physical disability and difficulties in maintaining proper oral hygiene, dental caries and periodontal disease are common [7-12]. Those two disease entities are the most common causes of teeth loss of adult patients [3, 13].

The aim of our study was to perform the first ever analysis of the degree of loss of masticatory function and number of teeth present for haemodialysis (HD) patients, and to define, based on the results, patients' needs for prosthetic treatment, which could restore correct occlusal condition. Additionally, we compared the results presented in the discussion to the results of a study by the All-Poland Monitoring of Oral Health of the

Table I. Numerical code of prosthetic status and prosthetic needs of all patients

\begin{tabular}{|c|c|c|}
\hline $\begin{array}{l}\text { Numerical } \\
\text { code }\end{array}$ & $\begin{array}{c}\text { Prosthetic } \\
\text { status }\end{array}$ & $\begin{array}{l}\text { Prosthetic } \\
\text { needs }\end{array}$ \\
\hline 0 & $\begin{array}{l}\text { No prosthetic } \\
\text { restoration }\end{array}$ & $\begin{array}{l}\text { No prosthetic } \\
\text { needs }\end{array}$ \\
\hline 1 & $\begin{array}{l}\text { Single unit } \\
\text { restoration }\end{array}$ & $\begin{array}{l}\text { Single unit } \\
\text { restoration }\end{array}$ \\
\hline 2 & One bridge & Multiple unit restoration \\
\hline 3 & $\begin{array}{l}\text { More than } \\
\text { one bridge }\end{array}$ & $\begin{array}{l}\text { Single and multiple } \\
\text { unit restoration }\end{array}$ \\
\hline 4 & $\begin{array}{l}\text { Removable denture } \\
\text { acrylic/skeletal }\end{array}$ & $\begin{array}{c}\text { Removable } \\
\text { acrylic denture }\end{array}$ \\
\hline 5 & $\begin{array}{l}\text { Bridge and } \\
\text { removable denture }\end{array}$ & - \\
\hline 6 & Full denture & Full denture \\
\hline 7 & $1+4$ & - \\
\hline
\end{tabular}

Polish Adult Population (Ogólnopolski Monitoring Stanu Zdrowia Jamy Ustnej Populacji Osób Dorosłych w Polsce). This was carried out in 65-74year-old patients in the years 1997 and 2002 and appointed by the Ministry of Health and Social Care (Ministerstwo Zdrowia i Opieki Społecznej) [14, 15].

\section{Material and methods}

General dental examinations were performed on 69 haemodialysis patients treated at the Nephrology and Transplantology Clinic with the Dialysis Centre at the Medical University of Bialystok, Poland (Klinika Nefrologii i Transplantologii z Ośrodkiem Dializ Uniwersytetu Medycznego w Białymstoku, Polska). The screened group consisted of a comparable number of male $(n=37)$ and female $(n=32)$ patients. All patients were of similar age (males $67 \pm 11$ years and females $62 \pm 14$ years). The majority of patients lived in cities $(n=52)$.

During the examination we especially checked: 1) the total number of teeth and number of teeth separately for upper and lower jaws, 2) the existing prosthetic restorations and 3) the preserved masticatory function. We described various types of prosthetic restorations using a numerical code (Table I). This allowed us to identify the prosthetic status separately for the upper and lower jaw in each patient. Based on tooth loss and prosthetic status analysis, we determined patients' prosthetic needs, namely which kind of prosthetic restoration would be the most appropriate for each patient to rebuild occlusal contacts and proper masticatory function. Table I shows the prosthetic needs described using the numerical code. The numerical code describing the prosthetic status and the prosthetic needs is based on guidelines from Polish Monitoring of Oral Health and its Determinants (Ogólnopolski Monitoring Stanu Zdrowia Jamy Ustnej i jego Uwarunkowań), which was drawn up especially for epidemiology screening in Poland by the WHO. Our study was conducted according to Good Clinical Practice Rules based on the Declaration of Helsinki. The protocol was accepted by the Bioethical Board at the Medical University of Bialystok. All the patients were informed of the study aims and agreed to take part in it.

The Statistica for Windows 9,0 PL software was used for statistical analysis of study results. Distribution of quantitative data was tested with the Shapiro-Wilk test. For the comparison of groups of quantitative data mainly Student's $t$-test and the Mann-Whitney $U$-test were used (depending on type of distribution of variables) and for the comparison of data in a nominal scale, the $\chi^{2}$ test was used. A two-sided test was used for all analyses and for a statistically significant value a probability level $(p)$ less than 0.05 was accepted. 
The studies for Monitoring of Oral Health were conducted by a validated research unit in accordance with WHO guidelines [2] in indexed age groups in Poland (16 provinces). The author of this paper (M. Wilczyńska-Borawska) was a member of the research unit in Podlaskie Province. The selection of the population for epidemiological study was randomised. In 1997, 698 people aged 65-74 years were checked. In 2002 there were 811 people included, divided into male, female, city/town and country dwellers.

\section{Results}

\section{Demographic and clinical data}

After dividing patients into two groups, depending on gender, we analysed basic demographic and clinical data (Table II). There were no statistically significant differences between the two groups regarding age or place of residency (age $p=0.149$; place of residency city vs. country: $p=0.407$ ). Even without statistical verification, the distinct majority of patients living in cities could be determined. More male than female patients were in possession of full dentition, but the difference was statistically insignificant (Table II). A similar situation was observed regarding differences in numbers of teeth in upper and lower jaws (all $p>0.05$, Table II). Males had more teeth in the upper jaw than females but women had more teeth in the lower jaw than men (Table II). There were no patients with a complete dentition in the female group. All patients with at least 28 natural teeth with retained occlusal contacts whilst chewing were males $(4 ; 10 \%$ males; $5.7 \%$ of the whole group, Table II). There were 15 edentulous patients: 7 males (10\%, Table II) and 8 females (11.5\%, Table II). No statistically significant differences were noted between the male and female patients regarding the use or absence of prosthetic restorations; retained masticatory functions were found in $30 \%$ of male and female patients (Table II).

\section{Prosthetic status}

In the test group 33 (12 females and 21 males) out of 69 patients $(47.82 \%)$ did not have prosthetic restoration ("0") in the maxilla and 41 (18 females and 23 males) out of 69 patients (59.42\%) in the mandible. The differences between groups of male and female non-users of prosthetic restorations were statistically significant for the maxilla ( $p=0.001$, Table III) but statistically insignificant for the mandible $(p=0.31$, Table III). Female patients were using prosthetic restorations in the upper jaw more often than males. However, after dental examination, we found that one male patient had complete dentition and he did not need any form of prosthetic restoration. In contrast, $100 \%$ of female patients presented with various degrees of tooth loss and needed prosthetic treatment. Subtracting 1 patient from the male group did not incur any statistically significant change in the results.

Only the male patients had any single unit restoration (e.g. crowns, implants, veneers, "1") both in the upper and lower jaws (2 patients, Tables III and IV). Because of the fact that none of the female patients had a single unit restoration in either the upper or lower jaws, the difference between male and female groups remained statistically significant (both $p=0.007$ ).

A similar situation occurred in patients fitted with dental bridges ("2"). Only 3 male patients had a single bridge in the upper jaw and one male patient in the lower jaw (Tables III and IV). The significance of a statistical difference $(p=0.001)$ is due to the absence of this kind of restoration in female patients (Tables III and IV). Two females in the test group had more than one bridge in the upper jaw ("3", Table III) and one in the lower jaw (Table IV) but

Table II. Collation of basic demographic information with selected clinical examination data

\begin{tabular}{|c|c|c|c|}
\hline Parameter & $\begin{array}{l}\text { Males } \\
(n=37)\end{array}$ & $\begin{array}{l}\text { Females } \\
(n=32)\end{array}$ & Value of $p$ \\
\hline Average age [years] & 67.43 & 62.96 & 0.149 \\
\hline $\begin{array}{l}\text { Place of residence } \\
\text { (country/city) }\end{array}$ & $29 / 8$ & $23 / 9$ & 0.407 \\
\hline Teeth in upper jaw $(n / \%)$ & $219 / 43.8$ & $124 / 41.6$ & 0.079 \\
\hline Teeth in lower jaw (n/\%) & $260 / 54.2$ & $174 / 58.3$ & 0.192 \\
\hline Total number of teeth $(n)$ & 479 & 298 & 0.105 \\
\hline $\begin{array}{l}\text { Patients with complete } \\
\text { dentition }(n / \%)\end{array}$ & $1 / 2.7$ & $0 / 0$ & \\
\hline $\begin{array}{l}\text { Edentulous patients } \\
(n / \%)\end{array}$ & $7 / 18.9$ & $8 / 25$ & \\
\hline $\begin{array}{l}\text { Existing prosthetic } \\
\text { restoration }(n / \%)\end{array}$ & $17 / 45.9$ & $20 / 62.5$ & 0.174 \\
\hline $\begin{array}{l}\text { Preserved masticatory } \\
\text { function }(n / \%)\end{array}$ & $11 / 29.7$ & $11 / 34.3$ & 0.685 \\
\hline
\end{tabular}

Table III. Prosthetic status of the upper jaw of haemodialysis patients

\begin{tabular}{|lccc|}
\hline Prosthesis & $\begin{array}{c}\text { Males } \\
(n / \% \text { from 69/ } \\
\text { \% from 37) }\end{array}$ & $\begin{array}{c}\text { Females } \\
(n / \% \text { from 69/ } \\
\% \text { from } 32)\end{array}$ & Value of $p$ \\
\hline 0 & $21 / 30.43 / 56.76$ & $12 / 17.39 / 37.5$ & 0.001 \\
\hline 1 & $2 / 2.9 / 5.41$ & $0 / 0 / 0$ & 0.007 \\
\hline 2 & $3 / 4.35 / 8.11$ & $0 / 0 / 0$ & 0.001 \\
\hline 3 & $0 / 0 / 0$ & $2 / 2.9 / 6.25$ & 0.003 \\
\hline 4 & $3 / 4.35 / 8.11$ & $2 / 2.9 / 6.25$ & 0.546 \\
\hline 5 & - & - & - \\
\hline 6 & $6 / 8.7 / 16.22$ & $12 / 17.39 / 37.5$ & 0.000 \\
\hline 7 & $2 / 2.9 / 5.41$ & $4 / 5.8 / 12.5$ & 0.034 \\
\hline
\end{tabular}


Table IV. Prosthetic status of the lower jaw of haemodialysis patients

\begin{tabular}{|lccc|}
\hline Prosthesis & $\begin{array}{c}\text { Males } \\
(n / \% \text { from 69/ } \\
\text { \% from 37) }\end{array}$ & $\begin{array}{c}\text { Females } \\
(n / \% \text { from 69/ } \\
\% \text { from 32) }\end{array}$ & Value of $p$ \\
\hline 0 & $23 / 33.33 / 62.16$ & $18 / 26.09 / 56.25$ & 0.31 \\
\hline 1 & $2 / 2.9 / 5.41$ & $0 / 0 / 0$ & 0.007 \\
\hline 2 & $1 / 1.45 / 2.7$ & $0 / 0 / 0$ & 0.056 \\
\hline 3 & $0 / 0 / 0$ & $1 / 1.45 / 3.13$ & 0.027 \\
\hline 4 & $4 / 5.8 / 10.81$ & $2 / 6.25 / 2.9$ & 0.172 \\
\hline 5 & - & - & - \\
\hline 6 & $5 / 7.25 / 13.51$ & $9 / 13.04 / 28.13$ & 0.002 \\
\hline 7 & $2 / 5.41 / 2.9$ & $2 / 2.9 / 6.25$ & 0.761 \\
\hline
\end{tabular}

none of the males had this kind of prosthetic restoration $(p=0.003)$. Both male and female patients used partial/skeletal dentures ("4", Tables III and IV). Five patients ( 3 males and 2 females) had upper dentures and six of them had lower dentures ( 4 males and 2 females). The statistical difference between the groups was insignificant (Tables III and IV). Complete dentures ("6") were used in the upper jaw by 18 patients ( 6 males and 12 females) and in the lower jaw by 14 ( 5 males and 9 females). Differences between the groups were statistically significant (both $p<0.05$, Tables III and IV). Women wore more complete dentures than men. Six patients had both single unit prosthetic restorations and partial dentures in the upper jaw and 4 of them in the lower jaw (Tables III and IV). A statistically significant difference was found only in correlation with the maxilla; more female patients compared to males were using both types of restorations ( $p=0.034$, Table III).

\section{Prosthetic treatment needs}

An analysis of prosthetic treatment needs in dialysis patients indicates that 32 people (14 males and

Table V. Prosthetic needs for the upper jaw for haemodialysis patients

\begin{tabular}{|lccc|}
\hline $\begin{array}{l}\text { Prosthetic } \\
\text { need }\end{array}$ & $\begin{array}{c}\text { Males } \\
(n / \% \text { from 69/ } \\
\% \text { from 37) }\end{array}$ & $\begin{array}{c}\text { Females } \\
(n / \% \text { from 69/ } \\
\% \text { from 32) }\end{array}$ & Value of $p$ \\
\hline 0 & $14 / 20.29 / 37.84$ & $18 / 26.09 / 56.25$ & 0.002 \\
\hline 1 & $1 / 1.45 / 2.7$ & $1 / 1.45 / 3.13$ & 0.832 \\
\hline 2 & $7 / 10.14 / 18.92$ & $4 / 5.8 / 12.5$ & 0.011 \\
\hline 3 & $13 / 18.84 / 35.14$ & $5 / 7.25 / 15.63$ & 0.000 \\
\hline 4 & - & - & - \\
\hline 5 & - & - & - \\
\hline 6 & $2 / 5.41 / 2.9$ & $4 / 5.8 / 12.5$ & 0.172 \\
\hline 7 & - & - & - \\
\hline
\end{tabular}

18 females) did not need any prosthetic treatment in the maxilla (Table V). The difference was statistically significant $(p=0.002)$ in favour of women more female patients did not need any form of prosthetic treatment compared to male patients. No statistically significant differences were noted regarding the mandible; 13 men and 14 women had a complete dentition or prosthetic restorations (Table VI). One woman and one man needed only single unit restorations ("1") in the maxilla ( $p$ statistically insignificant). In the male group the need for single unit fixed restorations is statistically significant when compared to the female group $(p=0.042$, Table $\mathrm{VI})$. Men required more multiple unit restorations in the maxilla ("2", partial dentures, skeletal dentures) ( $p=0.011$, Table V, a statistically significant difference) compared to women. Both males and females needed multipoint restorations in the maxilla (Table $\mathrm{VI}$ ). "Mixed" restorations ("3") were required more often by males in the maxilla ( $p<0.005$, Table $V$ ). Both groups had similar needs for this form of restoration in the mandible (Table VI). One male patient required partial denture ("4") in the mandible (Table VI) but both women and men needed complete ("6") upper and/or lower dentures (Tables $\mathrm{V}$ and $\mathrm{VI}$ ), and there were more lower dentures for females, a statistically significant difference (men vs. women $p=0.016$, Table VI).

\section{Comparison of dental status between haemodialysis patients and the general population of years 1997 and 2002}

Comparison of dental status between patients with renal disorders and the general population is shown in Table VII. The assessment of statistically significant differences between these groups was not possible, as there were no individual values for the general population $[14,15]$. The compared parameters were number of teeth, number of eden-

Table VI. Prosthetic needs for the lower jaw for haemodialysis patients

\begin{tabular}{|lccc|}
\hline $\begin{array}{l}\text { Prosthetic } \\
\text { need }\end{array}$ & $\begin{array}{c}\text { Males } \\
(n / \% \text { from 69/ } \\
\% \text { from 37) }\end{array}$ & $\begin{array}{c}\text { Females } \\
(n / \% \text { from 69/ } \\
\% \text { from 32) }\end{array}$ & Value of $p$ \\
\hline 0 & $13 / 18.84 / 35.14$ & $14 / 20.29 / 43.75$ & 0.137 \\
\hline 1 & $5 / 7.25 / 13.51$ & $2 / 2.9 / 6.25$ & 0.042 \\
\hline 2 & $8 / 11.59 / 21.62$ & $7 / 10.14 / 21.88$ & 0.952 \\
\hline 3 & $9 / 13.04 / 24.32$ & $6 / 8.7 / 18.75$ & 0.254 \\
\hline 4 & $1 / 1.45 / 2.7$ & $0 / 0 / 0$ & 0.059 \\
\hline 5 & - & - & - \\
\hline 6 & $1 / 1.45 / 2.7$ & $3 / 4.35 / 9.38$ & 0.016 \\
\hline 7 & - & - & - \\
\hline
\end{tabular}


Table VII. Comparison of dental status between patients with renal disorders and the general population

\begin{tabular}{|c|c|c|c|c|c|c|}
\hline & \multirow{2}{*}{$\begin{array}{l}\text { Number } \\
\text { of people }\end{array}$} & \multirow{2}{*}{$\begin{array}{l}\text { Average number } \\
\text { of teeth }\end{array}$} & \multicolumn{2}{|c|}{ Edentulous patients } & \multicolumn{2}{|c|}{ Patients with RMF } \\
\hline & & & $n$ & $\%$ & $n$ & $\%$ \\
\hline \multicolumn{7}{|l|}{ Whole group } \\
\hline General population $1997^{\star}$ & 698 & No data & 242 & 34.7 & 489 & 70.1 \\
\hline General population $2002^{* *}$ & 811 & 6.3 & 337 & 41.6 & 563 & 69.4 \\
\hline HD patients & 69 & 11.2 & 15 & 21.7 & 22 & 31.8 \\
\hline \multicolumn{7}{|l|}{ Females } \\
\hline General population 1997 & 400 & No data & 148 & 37.0 & 286 & 71.5 \\
\hline General population 2002 & 509 & 5.6 & 226 & 44.4 & 362 & 71.1 \\
\hline HD patients & 32 & 9.3 & 8 & 25 & 11 & 34.3 \\
\hline \multicolumn{7}{|l|}{ Males } \\
\hline General population 1997 & 298 & No data & 94 & 31.5 & 203 & 68.1 \\
\hline General population 2002 & 302 & 7.7 & 111 & 36.8 & 201 & 66.6 \\
\hline HD patients & 37 & 12.9 & 7 & 18.9 & 11 & 29.7 \\
\hline \multicolumn{7}{|l|}{ Town/city } \\
\hline General population 1997 & 441 & No data & 140 & 63.4 & 329 & 74.6 \\
\hline General population 2002 & 421 & 8.1 & 150 & 35.6 & 305 & 72.4 \\
\hline HD patients & 52 & 12.0 & 9 & 17.3 & 15 & 28.8 \\
\hline \multicolumn{7}{|l|}{ Country } \\
\hline General population 1997 & 257 & No data & 102 & 39.7 & 160 & 62.3 \\
\hline General population 2002 & 390 & 4.4 & 187 & 47.9 & 258 & 66.2 \\
\hline HD patients & 17 & 9.0 & 6 & 35.3 & 7 & 41.2 \\
\hline
\end{tabular}

*Based on epidemiological research 1997, **based on epidemiological research 2002, RMF-retained masticatory function

tulous patients and proportion of patients with retained masticatory functions. In the studied population of HD patients, the average number of retained teeth was greater than in epidemiological research carried out by Monitoring of Oral Health in both male and female groups and in city/town and country dwellers. There were also fewer edentulous patients in the population of haemodialysis patients. Less than half of the number of HD patients had reconstructed masticatory functions.

\section{Discussion}

Our study describes, for the first time, the prosthetic status and the prosthetic treatment needs in haemodialysis patients. A review of the literature (MEDLINE; key words: prosthetic status, prosthetic treatment needs, preservation of masticatory function, hemodialised, chronic renal insufficiency) suggests that no such study has been carried out before. As we established, nearly $70 \%$ of tested dialysed patients did not have a reconstructed masticatory function (Table II). This proportion is over twice as high as that of the general Polish population of a similar age $[14,15]$. The results suggest a high necessity of prosthetic treatment for chron- ically dialysed patients. It is surprising that so many HD patients did not have prosthetic reconstructions. It may be that treating dental problems is considered secondary to more serious medical concerns. Additionally, the older age of these patients with concomitant physical and manual deterioration may cause difficulties with access to dental surgery. Since tooth loss for those patients occurs earlier than for the general population, reconstruction of masticatory function and its quality makes it an important problem for them $[6,7]$. It is correlated with many factors predisposing to premature loss of permanent teeth. In our study conducted on a group of 105 haemodialysis patients in 2004, we made an attempt to assess the most important independent factors which determine dentition status for chronically haemodialysed patients from the North-East region of Poland [7]. Out of 11 independent demographic and clinical variables, the paramount predictors of oral health status in this specific population were as follows: age, female gender, place of residency (country), smoking, condition of the cardiovascular system and diabetes [7].

Our study confirmed these results. Female patients had fewer remaining natural teeth in both 
jaws compared to males and constituted a higher percentage of edentulous patients in the test group (Table II). Although more of them had their masticatory functions restored, implementation of prosthetic treatment was needed to a lesser degree (Tables V and VI). The statistical significance of the differences between groups may prove that women care more about oral health and aesthetics and visit specialists (prosthetic dentistry) more often. In the female group, more extensive restorations such as partial, skeletal and complete dentures were observed (Tables III and IV). This proves the fact that female patients in the haemodialysed population are predisposed to early tooth loss, especially when the majority of patients are postmenopausal. Bone metabolism changes of hormonal origin and osteoporosis play an essential role in this process [16]. Early tooth loss leads to disability of the whole stomatognathic system, gastric problems and decreased quality of life. Edentulousness and/or a residual dentition may lead to withdrawal from social interactions, facial cosmetic deterioration and speech defects. Deterioration of the masticatory system additionally impairs the independence and efficiency of these patients. It is impossible to separate proper functioning of oral physiology from the patient's general health. Masticatory system dysfunctions of haemodialysis patients can be directly correlated to the general disease and may also determine, to a certain degree, its clinical picture.

There is no clear evidence suggesting a correlation between edentulous state and the undernourishment of haemodialysis patients. Literature data indicate that $40-70 \%$ of dialysis patients are malnourished $[17,18]$. Moreover, this condition is one of the largest risk factors for the coexistence of systemic diseases and mortality of this population $[17,18]$. There are many causes of malnourishment in these patients: uraemia and its endocrinological complications (insulin resistance, secondary hyperparathyroidism), hypercatabolism and deaminisation, oxidation of amino acids and nutrition absorption impairment [19]. It is hard not to mention, often omitted in the literature, masticatory function disorders caused by early loss of permanent teeth. Hypovitaminosis and nutritional balance disorders play a key role in the formation and development of periodontal diseases and mucositis [2022]. There are many reports stating that haemodialysis patients present with diminished dentition status and suffer more often from periodontal inflammatory diseases compared to the general population $[6-8,10,12,23]$. This situation is determined by coexisting diseases, such as diabetes and other endocrinological disorders, systematic infections, humoral and cellular immunological disor- ders, atherosclerosis, oxidative stress and renal osteodystrophy [6-8, 10, 12, 23].

An especially troublesome xerostomia (dry mouth caused by reduced secretion of saliva) and elevated $\mathrm{pH}$ are not without importance [24]. They may cause rapidly progressing caries (the most important causative factor for early loss of permanent teeth) as the self-cleaning mechanism of the tooth surfaces is disabled and a deficiency of saliva buffer systems (carbonic acid/bicarbonate, phosphoric acid/phosphate) is present $[6,8,10]$. Furthermore, saliva alkaline $\mathrm{pH}$ favours quicker mineralization of dental plaque. It becomes more difficult to remove during everyday hygiene procedures and can cause periodontal disease (the second most common cause, after caries, of early loss of the permanent teeth) [3]. Coexistence of hypertension, atherosclerosis, diabetes, water impairments, depression and antidepressant usage can cause xerostomia for haemodialysis patients [6, 25]. It does not allow them to consume solid food or speak without sipping water and limits the use of prosthetic restorations, especially removable ones $[13,26]$. It is an interesting observation that the tested patients used mostly removable dentures (complete, partial, skeletal) which were causing discomfort. As we concluded in our study, the most important treatment need was to provide those patients (especially male) with fixed single or multiple unit restorations (crowns, bridges), which would give them comfort, especially when saliva secretion impairment was present. Lack of proper prosthetic care of haemodialysis patients was evident.

To summarise, the population of haemodialysis patients from the North East part of Poland are patients with severe stomatognathic system dysfunctions which developed as a result of the loss of physiological function of the masticatory system. This is due to a premature loss of teeth (more than $20 \%$ of patients were edentulous) and lack of prosthetic treatment reconstructing missing masticatory function. More than $70 \%$ of the studied population, despite using prosthetic restoration, did not reveal a properly reconstructed masticatory function as they did not have interdental occlusal contacts remaining, which allows the correct function of the stomatognathic system during chewing and speaking. The prosthetic treatment of these patients was incorrect and insufficient. Patients had old, worn out and non-functional restorations which they used only for a questionable aesthetic effect. It is of importance for dentists, as well as nephrologists, to understand the essence of the problem, as the general health of a patient cannot be improved without ensuring functional comfort of such a pivotal system as the masticatory one. 


\section{References}

1. World Health Organization. Periodontal disease. Report of an expert committee on dental health. Int Dent J 1961; 11: 544-9.

2. Oral Health Surveys. Basic Methods. 4th edition. World Health Organization. Geneva 1997.

3. Ong G. Periodontal disease and tooth loos. Int Dent J 1998; 48 (Suppl. 1): 233-8.

4. Seymour RA. Is oral health a risk for malignant disease? Dent Update 2010; 37: 279-80, 282-3.

5. Gerritsen AE, Allen PF, Witter DJ, Bronkhorst EM, Creugers $\mathrm{NH}$. Tooth loss and oral health-related quality of life: a systematic review and meta-analysis. Health Qual Life Outcomes 2010; 8: 126.

6. Klassen JT, Krasko BM. The dental health status of dialysis patients. J Can Dent Assoc 2002; 68: 34.

7. Wilczyńska-Borawska M, Borawski J, Stokowska W. Czynniki ryzyka utraty zębów u pacjentów przewlekle hemodializowanych [Polish]. Dent Med Probl 2004; 41: 751.

8. Bots CP, Poorterman JHG, Brand HS, et al. The oral health status of dentate patients with chronic renal failure undergoing dialysis therapy. Oral Dis 2006; 12: 176.

9. Collins AJ, Chen SC, Gilbertson DT, Foley RN. CKD surveillance using administrative data: impact on the health care system. Am J Kidney Dis 2009; 53 (Suppl 3): 27.

10. Davidovitch E, Schwarz E, Davidovitch M, et al. Oral findings and periodontal status in children, adolescents and young adults suffering from renal failure. J Clin Periodontol 2005; 32: 1076.

11. Eknoyan G. Salivary phosphorus binding: a novel approach to control hyperphosphatemia. J Am Soc Nephrol 2009; 20: 460 .

12. Franek E, Blaschyk R, Kolonko A, et al. Chronic periodontitis in hemodialysis patients with chronic kidney disease is associated with elevated serum C-reactive protein concentration and greater intima-media thickness of the carotid artery. J Nephrol 2006; 19: 346.

13. Petersen PE, Kandelman D, Arpin S, Ogawa H. Global oral health of older people: call for public health action. Community Dent Health 2010; 27 (4 Suppl 2): 257-67.

14. Wierzbicka M, Szatko F, Zawadziński M, et al. Ogólnokrajowy monitoring zdrowia jamy ustnej i jego uwarunkowań. Polska 2002 [Polish]. Ministerstwo Zdrowia, Zakład Stomatologii Zachowawczej Akademii Medycznej w Warszawie, Katedra Higieny i Epidemiologii Akademii Medycznej w Łodzi. Wydawnictwo Ministerstwa Zdrowia, Warszawa 2003.

15. Wierzbicka M, Szatko F, Radziejewska M, et al. Monitoring of Oral Health in Poland. Oral Health of Polish Residents at the Time of the Transformation of the Health Care System. The Ministry of Health and Social Care. Warszawa 1998.

16. Wactawski-Wende J. Periodontal disease and osteoporosis: association and mechanisms. Ann Periodontol 2001; 6: 197-207.

17. Thunberg BJ, Alagiri PS, Cestero RV. Cross-sectional and longitudinal nutritional measurements in maintenance hemodialysis patients. Am J Clin Nutr 1981; 34: 2005.

18. Uribarri J, Levin NW, Delmez J, et al. Association of acidosis and nutritional parameters in hemodialysis patients. Am J Kidney Dis 1999; 34: 493.

19. Ikizler TA, Flakoll PJ, Parker RA, et al. Amino acid and albumin losses during hemodialysis. Kidney Int 1994; 46: 830.

20. Lee JS, Weyant RJ, Corby P, et al. Edentulism and nutritional status in a biracial sample of well-functioning, community-dwelling elderly: the health, aging, and body composition study. Am J Clin Nutr 2004; 79: 295.
21. Musacchio E, Perissinotto E, Binotto P, et al. Tooth loss in the elderly and its association with nutritional status, socio-economic and lifestyle factors. Acta Odontol Scand 2007; 65: 78 .

22. Nowjack-Raymer RE, Sheiham A. Association of edentulism and diet and nutition in US adults. J Dent Res 2003; 82: 123.

23. Borawski J, Wilczyńska-Borawska M, Stokowska W, Myśliwiec $M$. The periodontal status of pre-dialysis chronic kidney disease and maintenance dialysis patients. Nephrol Dial Transplant 2007; 22: 457-64.

24. Wilczyńska-Borawska M, Borawski J, Myśliwiec M, et al. The effect of haemodialysis on salivary $\mathrm{pH}$ of patients with renal failure. Czas Stomat 2005; 7: 480.

25. Pajukoski H, Meurman JH, Halonen P, Sulkava R. Prevalence of subjective dry mouth and burning mouth in hospitalized elderly patients and outpatients in relation to saliva, medication, and systemic diseases. Oral Surg Oral Med Oral Pathol Oral Radiol Endod 2001; 92: 641-9.

26. Agrawal KK, Singh SV, Rashmikant US, Singh RD, Chand P. Prosthodontic rehabilitation in Sjogren's syndrome with a simplified palatal reservoir: Two year follow up. J Prosthodont Res 2011; 55: 248-51. 